\title{
Funding in Higher Education and Economic Growth in France and the United Kingdom, 1921-2003
}

\author{
Vincent Carpentier \\ Institute of Education, University of London, United Kingdom
}

The 2004 Higher Education Act generated important debates about the relationships between higher education (HE), economic growth and social progress. The range of positions expressed in relation to the increase of annual tuition fees raises crucial questions about the public and private funding of HE and its individual and social economic benefits. The analysis of new historical data from the 1920s onwards shows that the expansion in university resources was not linear and may be related to long economic cycles. Moreover, private funding periodically increased in order to replace diminishing public funding, rather than taking the form of additional resources. In consequence, private funds did not provide an overall rise in the universities' income. The considerable fluctuations of funding, combined with a more consistent growth of enrolment, led to a recurrent mismatch between resources for and access to HE, explaining the wide fluctuations of resources per student over the period. Such historical trends question whether, in the future, increased fees will be a substitute for public spending. Or will variable fees rather combine with even greater increases in public funding as part of a national project to support HE students from all social backgrounds and to boost expenditure per student?

\section{Introduction}

The close Parliamentary vote on the 2004 Higher Education Act confirmed the contentiousness of the issues addressed in the White Paper on the Future of Higher Education (DfES, 2003). The main controversy focuses on the implications of the introduction of variable annual student 
tuition fees of up to $£ 3,000$. Following the Dearing Report's recommendations (1997), the government considered higher fees as necessary additional resources in a context of competition from international universities. Access to HE will not be compromised, the government argues, because upfront fees are to be abolished and financial support is to be offered to students from poor backgrounds. But opponents have drawn attention to the deterrent effect of the increased levels of debt for students upon graduation (Callender, 2003) and a potential increase of inequality between higher education institutions (Ainley, 2005; Brown, 2005). Similar concerns were directed towards the Conservatives' counter proposition to replace fees with higher interest rates for students' loans (Carpentier, 2004a).

Although there is a consensus on the need to reform HE, different views are expressed about the extent and the nature of changes to be implemented. Most controversies focus on alternative ways of financing $\mathrm{HE}$ and on the orientation its development and democratisation should take. Key issues concern the relative contributions of private and public finance, the possible effects in terms of attendance and equity and the benefits for the society as a whole. The range of positions expressed in relation to top up fees raises crucial questions about the public and private funding of $\mathrm{HE}$ and its individual and social economic benefits (Barr, 2003a; Dearden et al, 2005).

This article draws on findings from an ESRC-funded research which sought to inform current debates by examining the long-term links between HE funding and economic fluctuations (Carpentier, 2004b). The aim was to construct and analyse historical series on funding and development of UK universities since the 1920s in order to explore continuities and contrasts with previous HE controversies. The analysis is strengthened through comparison with France where the UK debate starts having a strong resonance (Belloc, 2003; Aghion \& Cohen, 2004).

The article is divided into four parts. The first part presents the methodology. The second provides an overview of the main transformations of HE since the 1920s charting the fluctuations of funding and access. The third part draws on historical perspectives distinguishing different regimes of $\mathrm{HE}$ with specific articulations of funding and access policies. Finally, some conclusions are drawn. 


\section{1) A multidisciplinary approach on HE finance}

This article combines economic and historical perspectives within a quantitative approach in order to locate some of the socio-economic driving forces behind the expansion of HE.

\section{a) Economic theory and HE policy}

Both before and during the debates surrounding the White Paper, there have been fruitful attempts to assess the links between funding and access in HE and the economy (Barr, 1993; Williams, 1992) and to provide an answer to the fundamental question of "how to pay for mass, high quality higher education?" (Barr, 2003b). Following the path of human capital theory (Becker, 1962; Schultz, 1961), many research sought to evaluate and arbitrate between public and private funding of $\mathrm{HE}$ and its private (wages and social capital) and social (externalities) returns (Blundell et al, 2000; Mace, 2001; Chevaillier and Eicher, 2002; Wolf, 2002; Barr, 2003a; Johnstone, 2004).

This article seeks to contribute to these debates by examining the links between the funding and development of $\mathrm{HE}$ and socio-economic changes through the theory of systemic regulation. This theory attempts to interpret transformations of the economic system in terms of developing connections with spheres (like education) that are influenced, but not fully determined, by economic dimensions (Fontvieille, 1990; Michel, 1999). The theory suggests that, as education may not only represent a cost for the economy, but also furnish a main determinant of its growth, the development of the educational system may be interpreted, in part, as the outcome of regulation processes between public expenditure on education and long economic cycles.

Previous work has shown that the fluctuations of public expenditure on education in the UK since 1833 were connected to 50-year Kondratiev economic cycles (Carpentier, 2003). Moreover, the fluctuations were reversed to economic cycles before 1945 and then synchronised. Before 1945, the rapid growth of public expenditure on education during periods of economic downturn may be explained in terms of an attempt to revive the economy. On the contrary, after 1945, the growth of public educational resources accelerated during the period of post-war prosperity, only to go into decline following the economic crisis of 1973. The 1945 transition to procyclical public educational expenditure may represent the recognition of education as a driving force in the economic system rather than simply a means of correction. In this context, 
the post 1973 reforms would characterise different options in the search for a new regulation process in order to pursue educational development in a context marked by slowing down of public funding. Such framework strongly echoes the current debates on HE.

This article proposes to focus on the specific role of $\mathrm{HE}$ in such a process and seeks to investigate potential relationships between economic fluctuations and the level and structure of funding of $\mathrm{HE}$. The concept of regime of $\mathrm{HE}$ is proposed as an illustration of the interactions between the internal (quantitative and qualitative developments of HE) and external contexts (social change and economic fluctuations) that affect the evolution of HE. Historically, the successive regimes of HE would therefore characterise the degree of adequacy between funding and access policies as illustrated by the long-term fluctuations of funding per student.

\section{b) Towards a socio-economic history of education}

This theoretical framework interrogates economic and social interfaces with HE that were, and still are, major issues for policy making. As Aldrich noted, "the historical perspective indicates the complexity of the relationship between education and economic performance (1996, p. 109). The historical dimension is therefore crucial in order to reveal the long-term factors that could explain the current relationship between HE and economic systems. There is a mutual interest in combining economic and historical analysis to understand current educational policies. On the one hand, history can supplement the economic analysis which tends to elude the influence of cultural, social, and political factors on education. On the other end, some historians of education have recently pleaded for more recognition of the economic dimension in order to interpret past educational policies (Goodman and Martin, 2004; Richardson, 1999, p. 132).

The approach developed here can be defined as a socio-economic history of education following Simon's idea that "the fundamental educational issues have remained the same through the years - who should be educated, how, to what level or different levels of the service of what social or industrial needs? - So the conditioning social and economic factors continue to operate" (1989, p. 79). The aim of this article is to complement previous histories of HE (Briggs, 1969; Sanderson, 1972; Anderson 1992) with a particular focus on economic issues through a quantitative evaluation of the impact of past reforms on universities' funding and enrolment.

\section{c) A quantitative history of funding and development of UK universities (1921-2002)}


Following previous quantitative research on HE (Halsey and Webb, 2000), this study seeks to furnish data about the nature and level of financial resources for HE, and about the extent to which HE, in turn, affects the nature and level of resources. The methodology of quantitative history based on the principles of national accounting is used in order to collect and process long-term data (Marczewski, 1961).

The dataset, which gathers historical series on funding and development of universities from the early 1920s, is the result of research into primary and secondary governmental and institutional sources and is now part of the UK Data Archive (Carpentier, 2004c). Funding indicators include the level of the income of universities and its distribution according to its origins (public/fees/endowment/research), the level of expenditure and its distribution by economic categories (wages/consumption/investment). Non-financial data include the number of students and its distribution according to gender, country of origin and other enrolment's characteristics (full or part time and undergraduate or postgraduate), the number of awards and diplomas, the number and structure of staff.

These historical series refer to pre-1992 universities and include all institutions delivering degrees afterwards. It has been difficult to obtain historical data on expenditure relating to advanced courses in colleges of further education. It was also impossible to distinguish between resources devoted towards advanced and non-advanced courses within the same establishment. Prior to 1992, therefore, data are supplied only for universities. From 1994, data relating to advanced courses in polytechnics and further education are included.

In addition, the article proposes a comparative perspective dimension which is usually less common for HE than primary and secondary levels (Crook and McCulloch, 2002). A comparison with the French perspective is helpful in determining the uniqueness or otherwise of the UK development. Previous research has highlighted specific developments of HE in France and the UK in relation to their respective economic policies (Deer \& De Meulemeester, 2003). French data originate from Carry's (1999) quantitative work on education funding until 1996 and have been updated with governmental data (DEP, 1984-2003). Data on enrolment are based on the Annuaire Statistique de la France (DSG 1920-1945; INSEE, 1946-2003). Population data are based on Vallin and Meslé's (2001) work. 
The primary aim of this multidisciplinary examination is to investigate the mechanisms that regulated the articulation between the funding and development of HE and its relationship with the socio-economic system, seeking to resituate the complexity of the current situation.

\section{2) An overview of the growth of the HE system: 1921-2002}

Since the early 1920s, UK and French HE have experienced tremendous transformations. Among them, significant changes in the level and structure of universities' funding and enrolment may explain the current underfunding situation.

\section{a) The rise of funding and enrolment but the instability of expenditure per student}

The first result shows a dramatic increase of funding for UK and French universities. GearyKhamis $\$$ expresses purchasing power parity, eliminating differences in price level between countries (Maddison, 2000).

UK and French expenditure at 1990 prices in 2002 are respectively 150 and 180 times greater than in the 1920s. Over the period the share of GDP dedicated to the funding of universities rose from $0.06 \%$ to $1.4 \%$. The equivalent figures for France are respectively $0.06 \%$ and $1.11 \%$. 


\section{Figure 1 - Expenditures of universities (1990 Geary Khamis \$)}

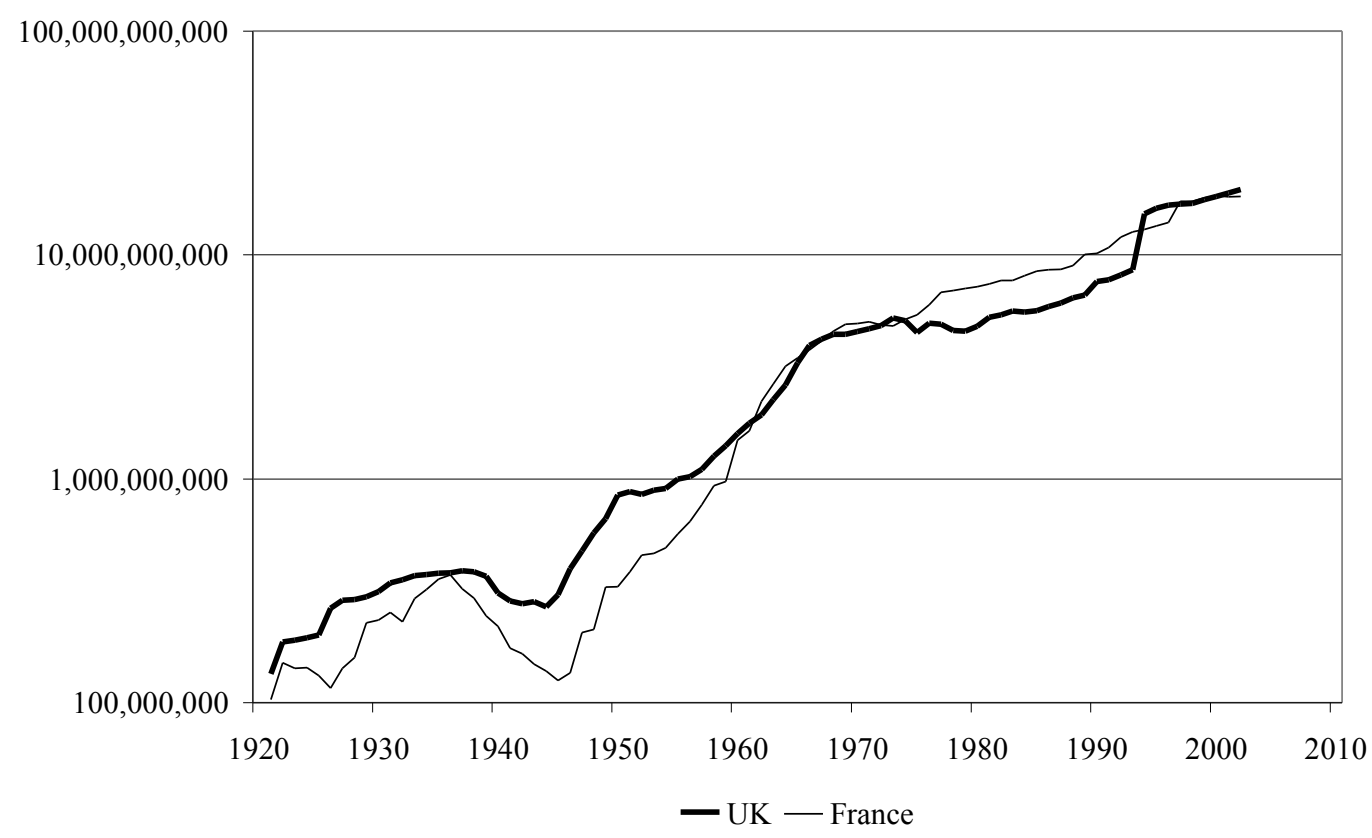

Source: Carpentier (2004c)

However, while expenditure increased, the number of students grew 40-fold in both countries. More significantly, the number of students in UK universities as a share of the 18-30 age group rose from $1.3 \%$ to $25 \%$ between 1955 and 2002. In France the ratio rose from $2.1 \%$ to $23 \%$ (Carpentier, 2004b). This rate is lower than the 43\% figure traditionally associated with participation and related to the famous 50\% target for 2010. These figures are for the Initial Entry Rate for HE - which sums the percentages of the age group who enter HE and further education colleges for the first time in each year of age between 18 and 30 (Ramsden, 2003). 
Figure 2 - Number of students in higher education, 1920-2002

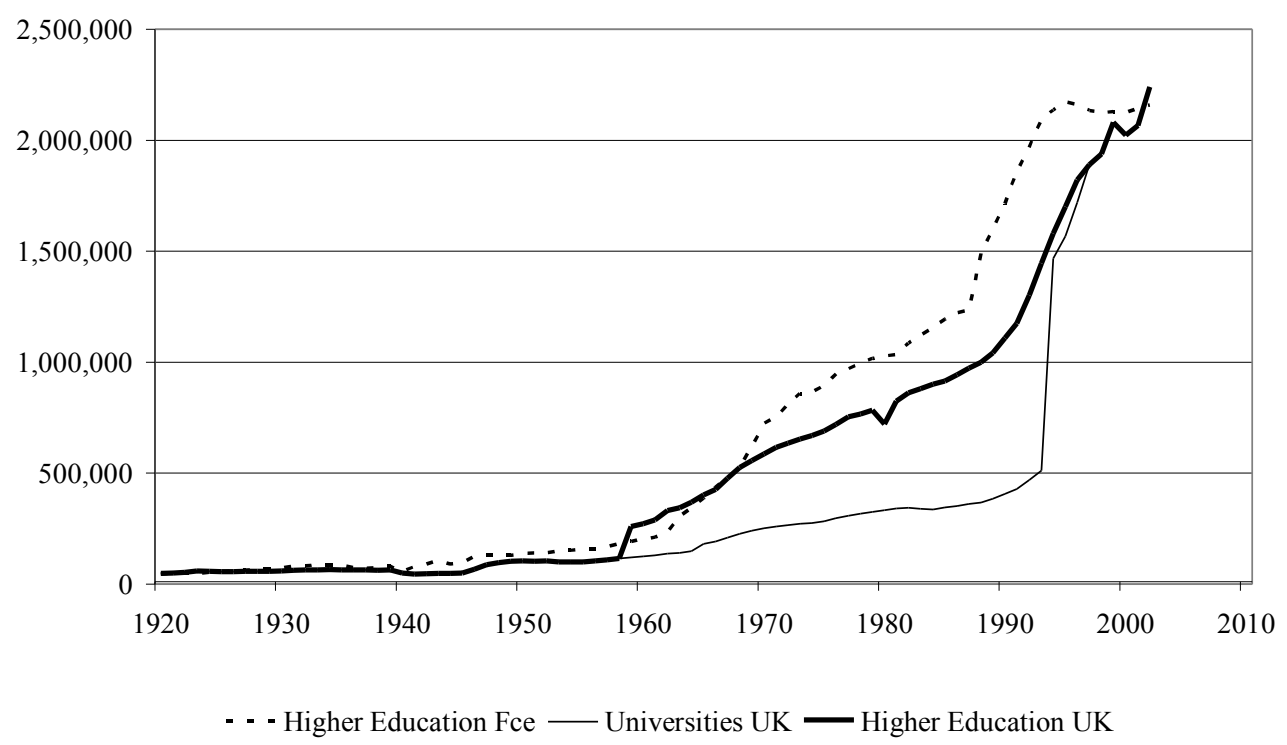

Source: Carpentier (2004c)

Over the whole period massive increases in enrolment were reflected in massive increases in funding. Nevertheless, there were considerable variations within this overall rise. For example, in 2002 expenditure per student in the UK was more than 3.5 times its level in 1921. In 2002, however, expenditure per student was less than a half of the level of 1973. It is worth noting that falling expenditure per student, which was one of the central issues of the White Paper, began in 1990, before the re-designation of the polytechnics. 


\section{Figure 3 - University expenditure per student (1990 Geary Khamis \$)}

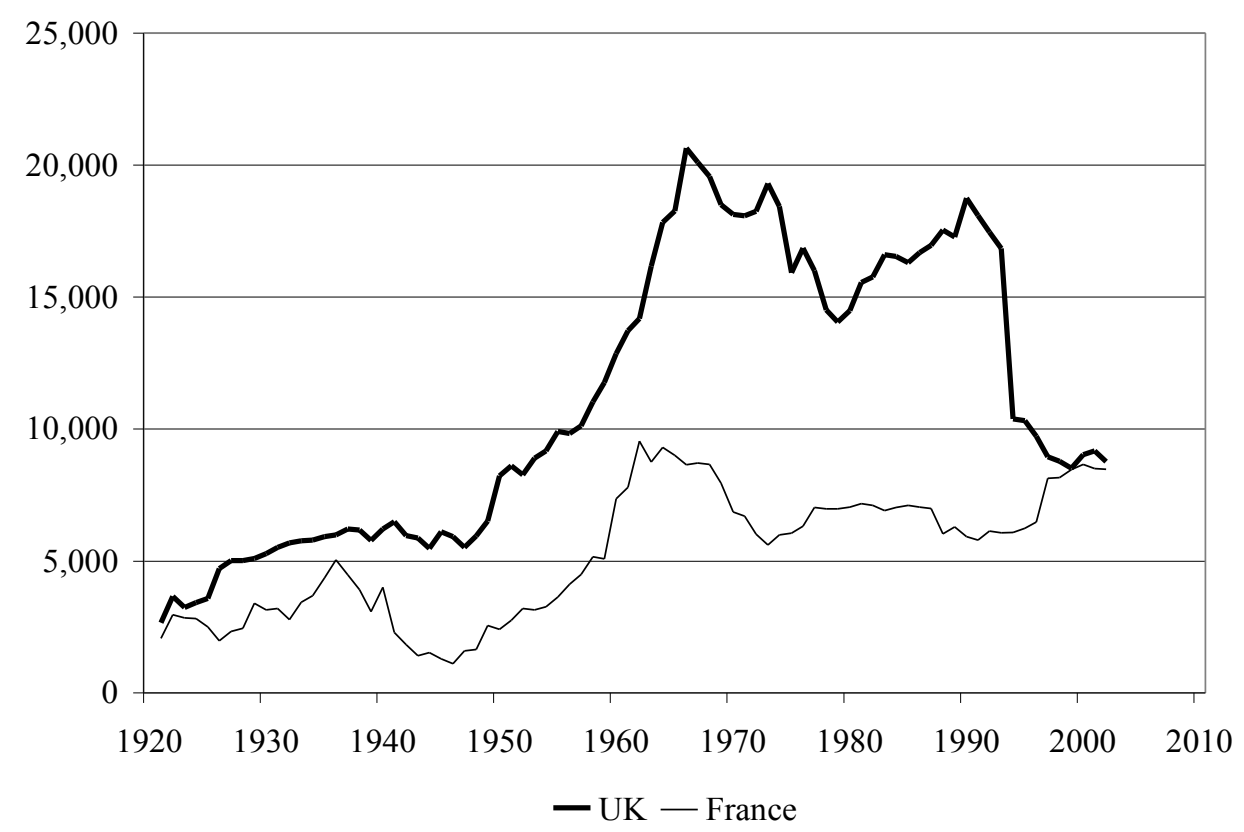

Source: Carpentier (2004c)

British and French expenditure per student were similar both at the beginning and at the end of the period. Much wider fluctuations, however, occurred in the UK. The following part examines the origins and consequences of these fluctuations by comparing and contrasting the historical evolution of funding and attendance.

\section{b) Level and structure of the university income and long economic cycles}

UK University expenditure conforms to the connections between resources and long economic cycles observed in other levels of education (Carpentier 2003). The long-term expansion in resources devoted towards HE was not linear and may be related to Kondratiev cycles (Figure 4). Four Kondratiev cycles of approximately 50 years have been identified, each showing expansion and depression phases (1790-1820/1820-1848; 1848-1870/1870-1897; 1897-1913/1913-1945; 1945-1973/1973-?) (Loucã and Reinjders, 1999).

The increase of expenditure during the 1920s was brought to a halt by the aftermath of the 1929 crisis. The period of prosperity following 1945 led to a dramatic rise of expenditure, although this was halted in 1967 as a consequence of a decrease in capital expenditure required for the 
establishment of new universities. The real funding downfall followed the oil crisis of 1973 and continued until the current period, although a revival of expenditure occurred in the early 1990s with the integration of polytechnics.

\section{Figure 4 - Fluctuation of university expenditure (1990 Geary-Khamis\$) (second order deviation from the regression curve and 9- year moving averages (MA))}

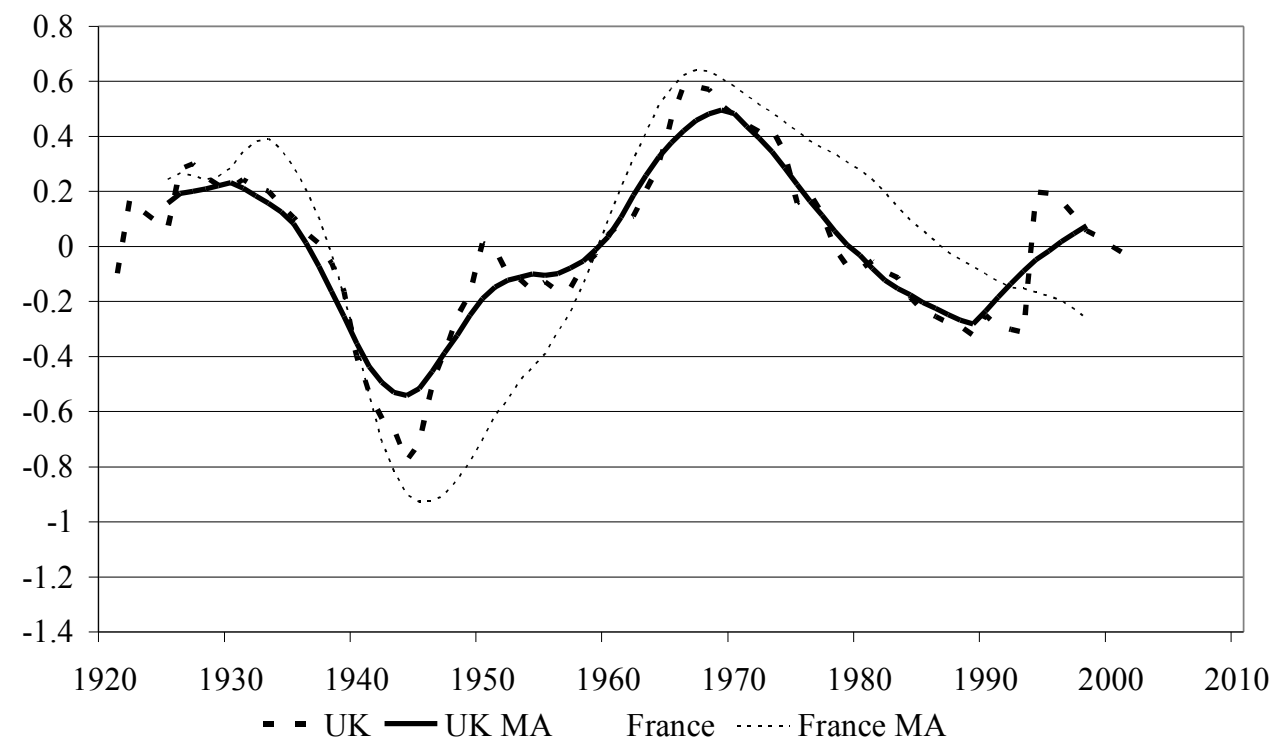

Source: Carpentier (2004c)

A similar pattern may be observed in France where fluctuations also corresponded to Kondratiev cycles. However, France and the UK experienced different evolutions with respect to the structure of HE funding. Despite some profound organisational transformations, especially since the 1980s (Musselin, 2004), the income structure of French universities did not change radically over the period. The rise of the share of private resources from 5\% in 1960 to $13 \%$ today indicates potential future developments rather than the transformation of a system which is still essentially publicly funded. In contrast, the relative contributions of public and private resources are key elements in the evolution of the income of UK universities. 
Figure 5 - Income of UK universities (£1990), 1921-2002

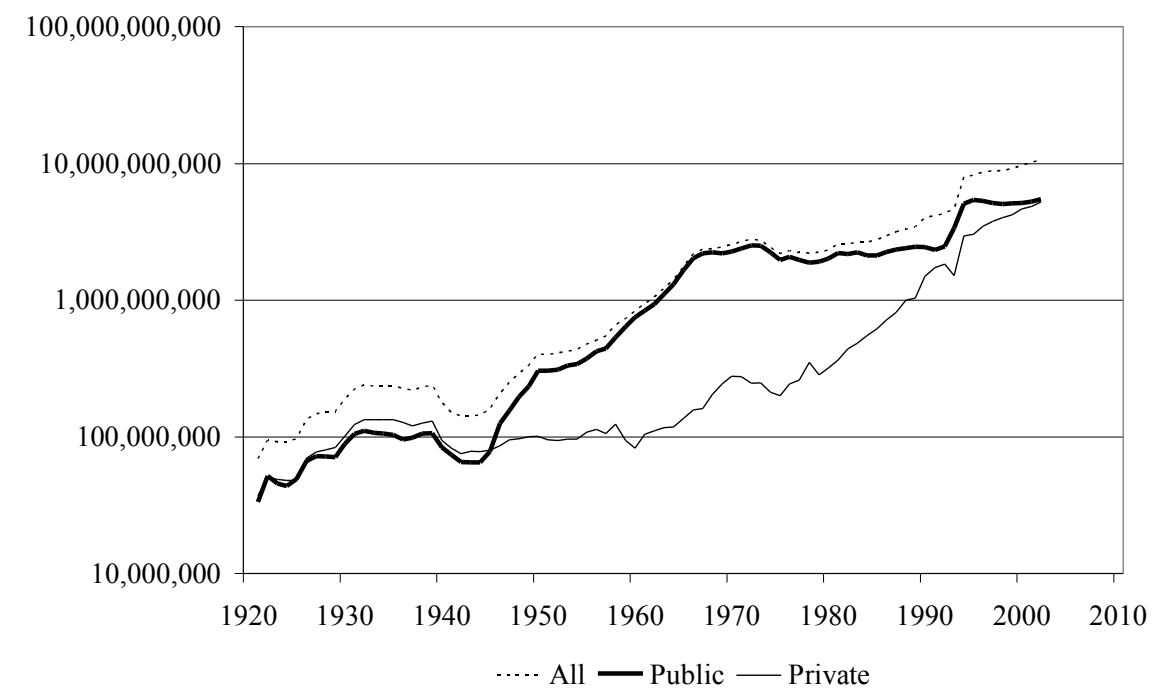

Source: Carpentier (2004c)

Figure 6 - Income structure of universities, UK, 1921-2002

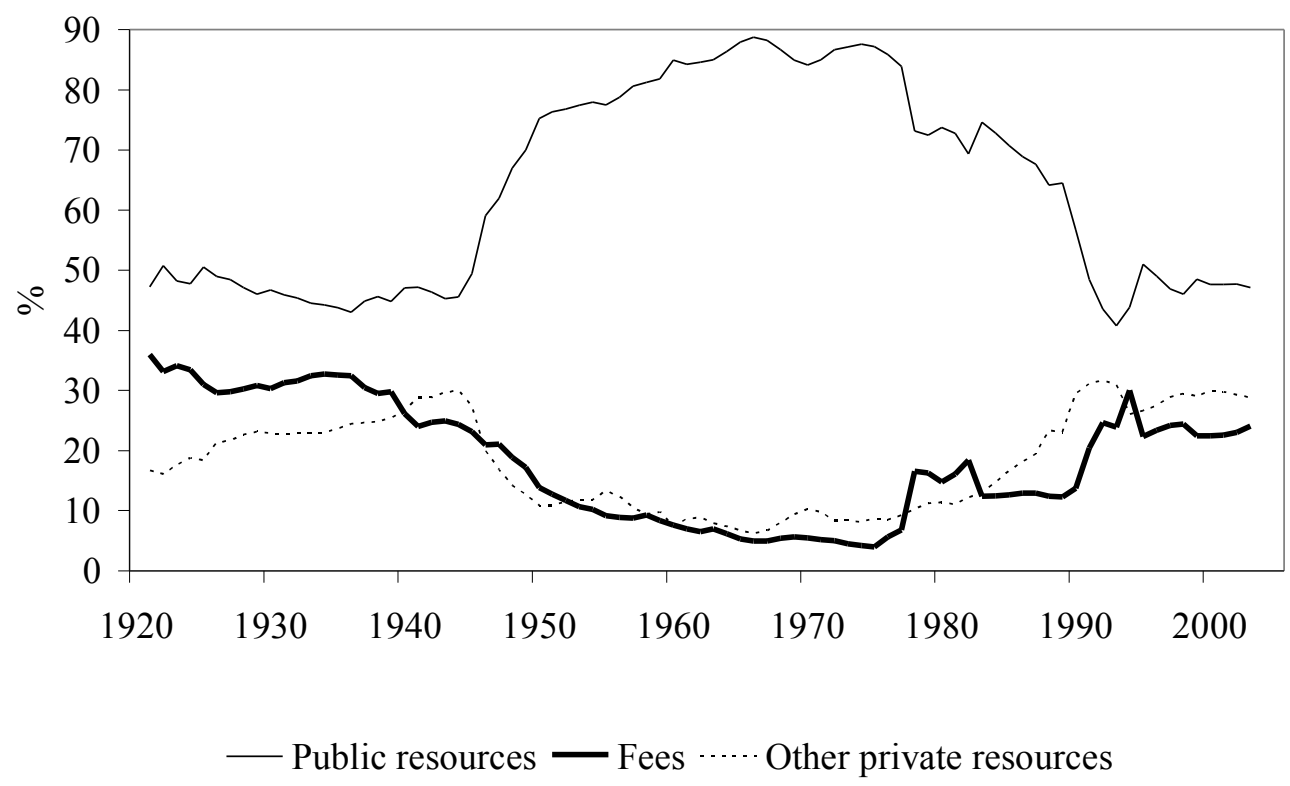

Source: Carpentier (2004c)

Figure 5 shows that public funding was the driving force of university income until the 1980s. Variations in public resources generated the Kondratiev-related fluctuations in university resources observed above. Public funding nourished the post-war growth of university income and put a brake on it after 1973 in the context of spending cuts. The revival of income growth did 
not take place until the early 1980s with a rise in private funding. However, such an increase did not fully compensate for the reduction in public funds and so only partially restored the overall growth in income.

Figure 6 shows that such movements led to substantial changes in the repartition between public and private income of universities. Between 1921 and 1945 public and private resources contributed in broadly equal amounts to the income of universities. Thereafter the share of public funding rapidly increased and reached $90 \%$ in 1973. It then fell, so that by the beginning of the twenty-first century the 50/50 distribution had been restored.

Research was also a major part of the transformation of the income structure of universities. The share of university specific funding dedicated to research increased from $5 \%$ in 1957 to $15 \%$ in 2002. The share of public funding of research increased from $50 \%$ to $65 \%$ from 1957 to 1973 and then started declining to reach 57\% in 2002.

The effect of public funding on the income structure of educational institutions was crucial in the development of enrolment in primary education in the late nineteenth century and in secondary education during the first half of the twentieth century (Carpentier, 2003). Such mechanisms became increasingly important in HE where access policies were still affected by a mixture of public and private funds. 
Figure 7 - Characteristics of students, UK, 1921-2002

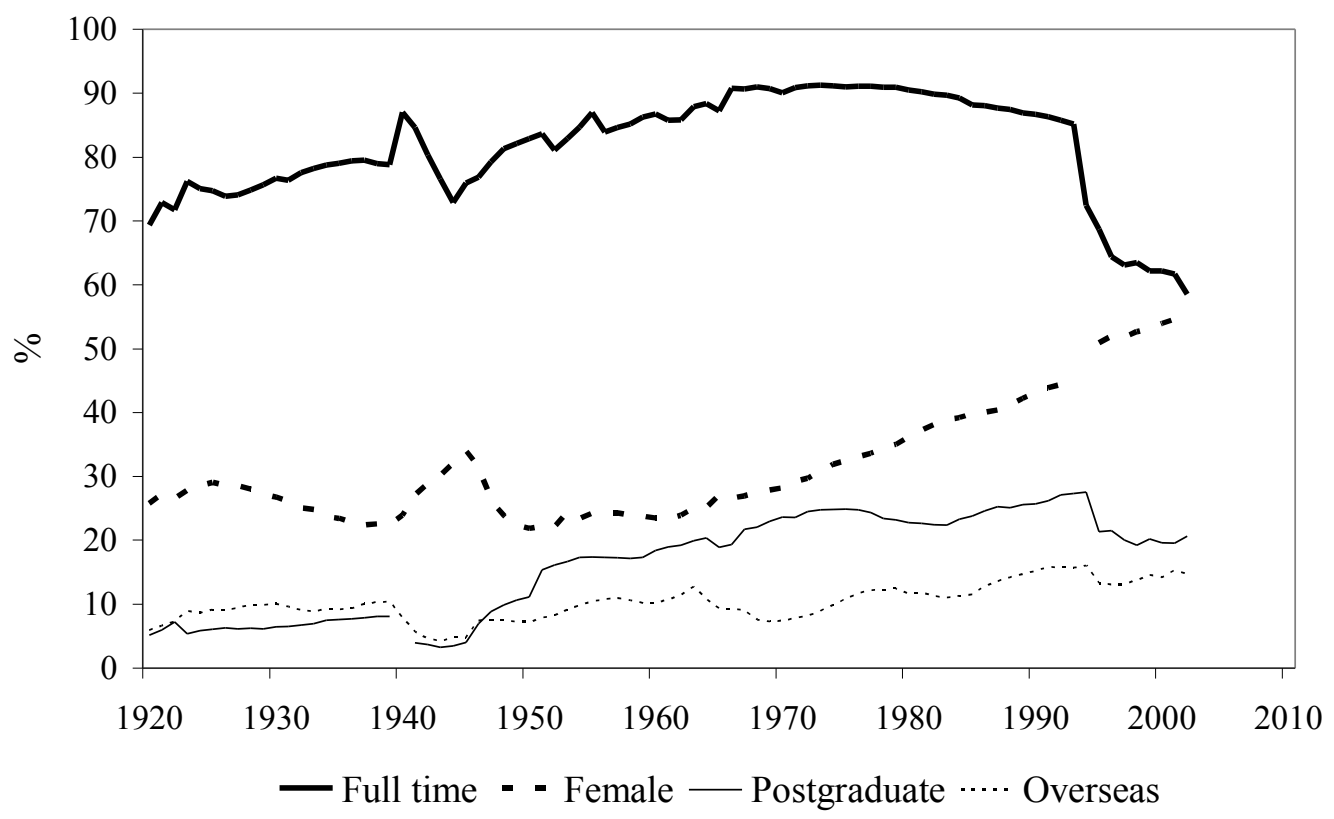

Source: Carpentier (2004c)

Between 1921 and 1974 the share of university income originating from fees decreased from $36 \%$ to $4 \%$ and rose thereafter to reach $23 \%$ in 2002 (Figure 6). Such changes may have influenced enrolment's extent and characteristics, especially as tuition fees are one of the main factors affecting access. Economic cycles and public resources had an impact on the structure and levels of funding of universities and on the replacement of fees by public funding. This leads to the crucial question: Does access drive funding or funding drive access or both? Increased enrolment was accompanied by a decrease of fees from 1945 to 1973 (Figure 6), especially after 1958 and the implementation of tuition fees subsidies. The post 1973 era led to the partial withdrawal of subsidies in a context of the control of public funding. The number of new students slowed down during the 1980s to grow again during the 1990s. The impact of the increase of fees on access depends on the crucial role of financial aid to poorer students.

Fluctuations of public expenditure may be associated not only with the number of students but also with a change of their characteristics. The proportion of postgraduate rose from $6 \%$ to $23 \%$ from 1947 to 1973 and remained stable afterwards. The share of full time students rose from $69 \%$ to $90 \%$ over the same period and has subsequently dropped to $58 \%$ nowadays. 
In contrast, the share of women students was not affected by economic fluctuations (Figure 7). This confirms Dyhouse's findings that the proportion of women in HE increased during the 1960s and even more dramatically during the 1970s for various reasons like the drop in early marriages, the new universities of the 1960s, the end of quotas, and more career opportunities for women graduate (2005). Therefore, alongside economic explanations, feminisation should be considered as a major factor of the historical expansion of HE enrolment and funding.

Figure 8 - Numbers of students per full time academic staff, UK, 1926-2002

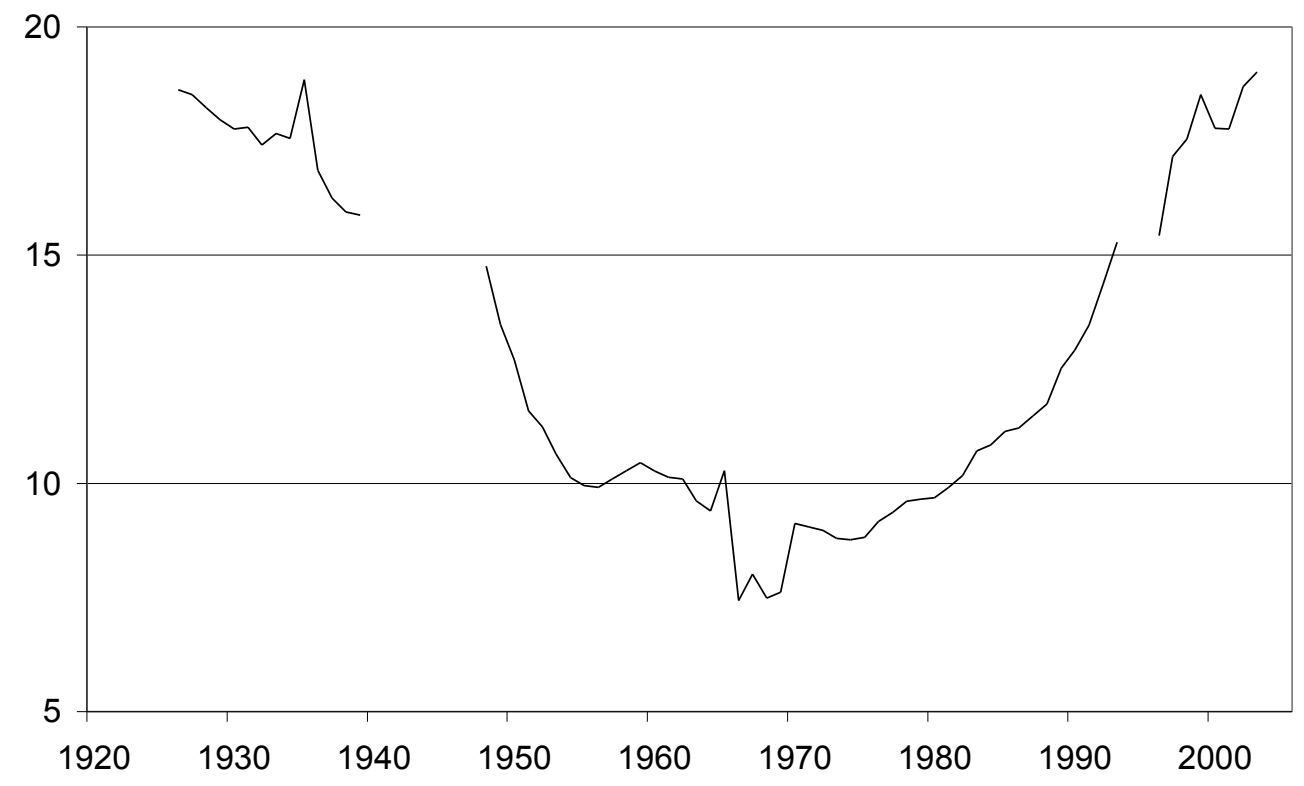

Source: Carpentier (2004c)

As a whole, all those indicators suggest that the elite system provided many resources compared to the limited number of students, prior to the mass system that developed in the 1960s in a context of growing funding. The increase of enrolment was maintained in the 1970s in a context of diminishing resources.

In this context, access might have been developed to the detriment of quality. Figure 8 shows that the student/full-time staff ratio decreased until the early 1970s and increased thereafter. This increase may also be the consequence of the casualisation of staff. 


\section{3) Regimes of HE: the historical articulation between funding and access policies}

The following provides a long-term description of the evolutions of expenditure per student by revealing different historical sequences of articulations between the funding and access policies.

Figure 3 and 9 clearly show different upward and downward phases of expenditure per student, suggesting the alternations of different regimes of HE.

Figure 9 - University expenditure (£1990), UK, 1921-2002 (Second-order deviation from the regression curve and nine-year moving averages (MA)), $\mathbf{R}^{2}=0,949$

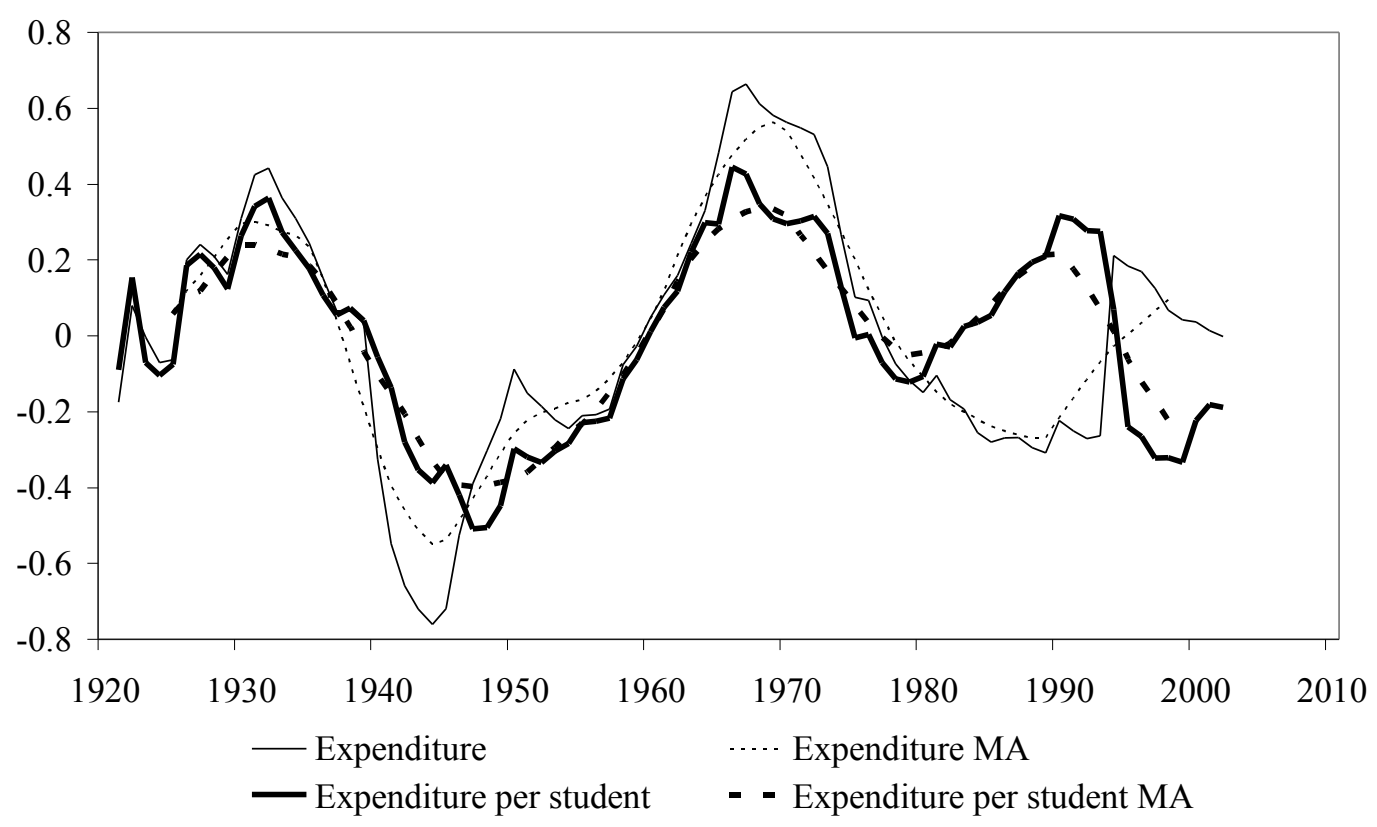

Source: Carpentier (2004c)

The notion of a regime of HE seeks to characterise the articulations between the internal development of universities (funding, access, staff, quality) and their external socioenvironments (economic fluctuations and social changes). The following seeks to identify these regimes and to examine the factors behind the transition from one to another in order to place the current situation in perspective. 


\section{a) 1921-1932 rise of spending per student: more resources for a limited enrolment}

The creation of the University Grants Committee in 1919 symbolised the growing involvement of the State (Shinn, 1980; Shattock, 1994) in a context where public expenditure increased from 5 to $10 \%$ of GDP. Education's share of all public expenditure grew from $6 \%$ to $10 \%$. However, the share of public expenditure on education devoted towards HE remains stable at around $2 \%$. The structure of university income did not change as increasing private and public resources equally drove the rise in funding. University expenditure was multiplied by 3.5. Enrolment was growing at a slower pace than funding, which explains the doubling of expenditure per student over the period.

\section{b) 1933-1944 decrease of spending per student: the stagnation}

The great depression led to the decrease of non-military public expenditure as a share of GDP. Such movement particularly targeted public expenditure on education which stagnated from 1932 and decreased during the war (Carpentier, 2003). The slower growth of university funding was the result of a brake upon both public and private resources (Figure 5). Both expenditure and enrolment stagnated and decreased during the war. It is worth noting that reductions in the former preceded the latter. The stagnation of expenditure combined with a moderate growth of enrolment explains the decrease of expenditure per student.

\section{c) 1945-1967 the Robbins era or the golden age}

The golden era of British universities is traditionally associated with the Robbins Report (1963) that Lowe considers as the first attempt to co-ordinate the development of a system of higher education in modern Britain (2000, p. 83). Nevertheless, the rise of enrolment started earlier. Enrolment rose threefold until 1967 and its share of the 18-30 year old age group rose from 2\% to $6 \%$ (Figures 2). One important aspect of this period was that increases in funding preceded the growth of enrolment. This was part of a context where public expenditure on education's share of GDP rose from $2 \%$ to $6 \%$. HE's share of public expenditure on education increased from $3 \%$ to 12\%. While public involvement became orientated to all universities (Salter and Tapper, 1994), the share of university income from public funding grew from $50 \%$ to $90 \%$. 
Increases in funding were greater than the growth of enrolment, thus explaining the considerable rise in expenditure per student. Increased public funding promoted enlarged access, by the removal or reduction of fees, and sustained a qualitative development as shown by the decrease in the numbers of student per staff. Students of 1973, as compared with their counterparts in the 1950 s, were increasingly female (from $22 \%$ to $30 \%$ ), studying on a full-time basis (from $72 \%$ to $90 \%$ ) and with greater participation at postgraduate level (from 6\% to 24\%) (Carpentier, 2004c).

Quantitative and qualitative indicators suggest that this phase was really the "golden age" for HE when funding improved access without harming quality.

\section{d) 1967 to 1980 between cuts in spending and democratisation}

The 1973 oil crisis opened a new era which marked a decline in public funding of the educational system (Carpentier, 2003). For universities, reductions began in 1967 in a context of declining capital expenditure on new universities which indicated the end of the Robbins era. The major slowdown, however, took place in the aftermath of the 1973 economic crisis. Reductions in public funding were not compensated for by increased private resources (Figure 5). Therefore, the overall level of university income dropped.

The conjunction of high enrolment and a reduction in overall resources led to a $25 \%$ decrease of expenditure per student from 1967 to 1980 . This period demonstrates a mismatch between funding and access policy that is also observed in France where funding per student dropped from $20 \%$.

\section{e) 1980-1990 the virtual expansion of funding per student}

The increase of funding per student during this period was caused by a slowdown in the growth of numbers of students combined with a modest increase in funding. The number of new students was stable while the number of international students increased. Reductions in public funding, coupled with a rise from private sources (fees from overseas students and private research), produced a dramatic shift in the public/private income structure (from $86 \% / 14 \%$ to $56 \% / 44 \%$ ). Access grew slowly and reductions in staffing led to a rise in the student/staff ratio (Figure 8). Staff wages as a share of expenditure fell from 55\% to $48 \%$ (Carpentier, 2001). The increasing expenditure per student was not the result of higher enrolment connected to even greater rise of 
funding like it was the case during the Robbins era but was on the contrary the combination of a slower growth of access and a policy of public austerity for which the rise of private funding did not fully compensate.

\section{f) 1990 s the growing disconnection between funding and access}

A decline in public funding coupled with an increase in private resources produced a modest rise of total income but the explosion of enrolment led to a dramatic setback in spending per student. The important result is that the downward trend took place as soon as 1990 when subsidies were replaced by loans and before the 1992 act. The polytechnics, whose expenditure per student was lower than pre-1992 universities, deepened the lack of resources per student of the HE system as a whole but did not provoke it. Moreover public grant constitutes 35\% of income of traditional universities against 55\% for new universities (Webber, 2003). As a result, trends towards more private funding slowed down in 1993 before rising again in 1995. Thus integration into the university sector increased polytechnics' reliance on private income.

\section{g) 1999-? The stabilisation}

In 1999, a brake was applied to the decrease of expenditure per student which began in the 1980s. This new regime of growth is based upon an increase of both public and private resources (the increase of public funding was combined with the increase of fees in 1998 and the rise of private funding for research). Increasing income contrasts with the previous period but does not compensate for the rapid growth of student numbers. The expenditure per student is then stabilised. The White Paper proposed to increase the level of income of universities and to change the structure of funding.

\section{4) Conclusion}

The study has provided evidence of the juxtaposition of several time periods. The passage from one regime of HE to another can be connected with economic fluctuations, social changes and demography articulated around five turning points:

1945 the beginning of massive public funding; 
1963 the expansion of enrolment

1973 the control of public expenditure

1980 the beginning of private expenditure expansion

The combinations of those factors led to a reversal of the link between funding and access policies in the early 1980s. Figure 9 shows that:

- Until 1980, access and funding fluctuate in the same direction, the latter driving the former.

- After 1980 they have conflicting trends. Funding level and structure of income are still linked with economic cycles' impact on public expenditure while access fluctuations progressively became less dependent on economics.

The historical perspective can illustrate the successive changes that led to this reversal and the current debates:

- The long-term expansion of universities' resources in the UK was not linear and a consistent link was found with 50-year Kondratiev economic cycles. Post-war growth, ended by the oil crisis of 1973 corresponded with acceleration and, later, a slowdown of funding. Economic cycles provoked not only changes in the level of expenditure of universities but also dramatic shifts in their income structure. Public funding was the driving force for university income until the 1980s.

- In the past, private funding (including fees) periodically increased in order to replace diminishing public funding, rather than taking the form of additional resources. In consequence, private funds did not provide an overall rise in the income of universities.

- the considerable fluctuations of structure and levels of funding, combined with a more consistent growth of enrolment, led to a recurrent mismatch between resources for and access to HE, explaining the wide fluctuations of expenditure per student over the period.

With respect to policymaking, such historical trends question whether, in the future, increased fees will be a substitute for public spending. Or will higher fees rather combine with even greater increases in public funding as part of a national project to support HE students from all social backgrounds and to boost expenditure per student? 


\section{References}

AGHION, P. \& E. COHEN (2004), Education et Croissance: Rapport pour le Conseil d'Analyse Economique, La documentation Française, Paris.

AINLEY, P. (2005), For Free Universities, Inaugural Lecture, University of Greenwich, 19 January.

ALDRICH, R. (1996), Education for the Nation, Cassell, London.

ANDERSON, R. D. (1992), Universities and Elites in Britain Since 1800, Macmillan, Basingtoke.

BARR, N. (1993), “Alternative Funding Resources for Higher Education”, Economic Journal, Vol. 103, pp. 718-728.

BARR, N. (2003a), Financing Higher Education: Comparing the Options, LSE Working Paper Series, June.

BARR, N. (2003b), "Financing Higher Education: Lessons from the UK Debate", The Political Quarterly, Vol. 74, No. 3, pp. 371-381.

BECKER, G. S. (1962), "Investment in Human Capital: A Theoretical Analysis ", The Journal of Political Economy, Vol. 7, No. 5, pp p. 9-49.

BELLOC, B. (2003), "Incentives and Accountability Instruments of Change", Higher Education Management and Policy, Vol. 15, No. 1, pp. 23-40.

BLUNDEL, R.; DEARDEN, L; GOODMAN, A. and H. REED (2000), "The Returns to Higher Education in Britain: Evidence from a British Cohort", Economic Journal, Vol. 110, pp. F82F99.

BRIGGS, A. (1969), "Development of Higher Education in the United Kingdom: Nineteenth and Twentieth Centuries", in: Niblet, W. R. (ed.), Higher Education: Demand and Response, Routledge, London, pp. 95-116.

BROWN, R. (2004), “The Future Structure of the Sector: What Price Diversity?”, Perspectives, Vol. 8, No. 4, pp. 93-99. 
CALLENDER, C. (2003), "Student Debt: The Impact on Participation in Higher Education", Universities UK Seminar on Student Debt, 5 February, London.

CARPENTIER, V. (2001), Système éducatif et performances économiques au Royaume-Uni: $19^{\text {ème }}$ et $20^{\text {ème }}$ siècles, L'Harmattan, Paris, 2001.

CARPENTIER, V. (2003), "Public Expenditure on Education and Economic Growth in the UK, 1833-2000", History of Education, Vol. 32, No. 1, pp. 1-15.

CARPENTIER, V. (2004a), “An Elitist's Manifesto", Times Higher Education Supplement, 17 September.

CARPENTIER, V. (2004b), "Higher Education and the UK Socio-Economic System", ESRC Research Report, RES-000-22-0296.

CARPENTIER, V. (2004c), Historical Statistics on the Funding and Development of the UK University System, 1920-2002, UK Data Archive (http://www.data-archive.ac.uk)

CARRY, A. (1999), "Le compte satellite rétrospectif de l'éducation en France (1820-1996)", Economies et Sociétés, Série AF, Histoire quantitative de l'économie française, Vol. 25, pp. 1281.

CHEVAILLIER, T. and J. C. EICHER. (2002), "Rethinking the Financing of Post Compulsory Education ", Higher Education in Europe, Vol. 27, No. 1-2, pp. 69-88.

CROOK, D. and G. MCCULLOCH (2002), "Comparative Approaches to the History of Education", History of Education, Vol. 31, No 5, pp. 397-401.

DEARDEN, L.; FITZIMONS, E.; GOODMAN A. and G. KAPLAN (2005), Higher Education Funding Policy: Who Wins and Who Loses?, IFS Commentaries.

DEARING, R. (1997), The National Committee of Inquiry into Higher Education: Higher Education in the Learning Society, H. M. S. O..

DEER, C. \& DE MEUlemeEster, J. L. (2003), "The Political Economy of Educational Reform in France and Britain: 1980-2000, Compare, Vol. 34, No 1, pp. 33-51.

DfES, (2003), The Future of Higher Education, White Paper, Department for Education and Skills, January.

DEP (1984-2003), Repères et références statistiques sur les enseignements, la formation et la recherche, Direction de l'évaluation et de la prospective, Ministère de l'Education, Paris. 
DSG (1920-1945), Annuaire statistique de la France, Direction de la Statistique Générale, Paris.

DYHOUSE, C. (2005), "Women in Universities: An Historical Perspective", ESRC Research Report, (RES-000-22-0139).

FONTVIEILLE, L. (1990), "Education, Growth and Long Cycles" in: Tortella, G. (ed.) Education and Economic Development since the Industrial Revolution, Generalitat, Valencia, pp. 317-335.

GOODMAN, J. and J. MARTIN (2004), "Editorial: History of Education-Defining a Field", History of Education, Vol. 33, No. 1, pp. 1-10.

HALSEY, A. H. and J. WEBB (2000), Twentieth Century: British Social Trends, Macmillan Press Ltd, London.

INSEE (1946-2003), Annuaire statistique de la France, Institut National de la Statistique et des Etudes Economiques, Paris.

JOHNSTONE, B. (2004), "The Economics and Politics of Cost Sharing in Higher Education: Comparative Perspectives", Economics of Education Review, Vol. 23, No. 4, pp. 403-410.

LOUCA, F. and J. REIJNDERS (1999), The Foundations of Long Wave Theory, Edward Elgar Publishing, Cheltenham.

LOWE, R. (2002), "Higher Education", in: ALDRICH, R. (ed.) A Century of Education, RoutledgeFalmer, London, pp. 75-92.

MACE, J. (2001), “Top-Up Fees: Theoretical and Policy Issues”, Higher Education Review, Vol. 34, No. 1, pp. 3-19.

MADDISON, A. (2000), The World Economy: A Millennial Perspective, O.E.C.D., Paris.

MARCZEWSKI, J. (1961), "Histoire quantitative, buts et méthodes ", Cahiers de l'Institut de Sciences Economiques Appliquées, Série A.F., Vol. 115, No. 1, pp. 3-54.

MICHEL, S. (1999), Education et croissance économique en longue période, L'harmattan, Paris. MUSSELIN, C. (2004), The Long March of French Universities, RoutledgeFarmer, London. RAMSDEN, B. (2003), Review of the Initial Entry Rate into Higher Education, National Statistics Quality Review Series, Department for Education and Skills. 
RICHARDSON, W. (1999) "Historians and Educationists: The History of Education as a Field of Study in Post-War England Part II: 1972-96”, History of Education, Vol. 28, ’o2, pp. 109141.

ROBBINS, L. (1963), Higher Education, Report and Appendices, H.M.S.O., London.

SALTER, B. and T. TAPPER (1994), The State and Higher Education, Woburn Press, London.

SANDERSON, M. (1972), The Universities and British Industry 1850-1970, Routledge \& Kegan Paul, London.

SCHULTZ, T. W. (1961), "Investment in Human Capital", The American Economic Review, Vol. 51, No. 1, pp. 1-17.

SHATTOCK, M. (1994), The UGC and the Management of British Universities, Society for Research into Higher Education, Guildford.

SHINN, C. H. (1980), "The Beginnings of the University Grants Committee", History of Education, Vol. 9, No. 3, pp. 233-243.

SIMON, B. (1989), "The History of Education", in: Gordon, P. and R. Szreter (eds.) History of Education: the Making of a Discipline, The Woburn Press, Paris, pp. 55-72.

VALLIN, J. and F. MESLE (2001), Tables de mortalité francaises pour les XIXe et XXe siècles et projections pour le XXIe siècle, INED, Paris.

WEBBER, G. (2003), "Funding in UK Universities: Living at the Edge", Perspectives, Vol. 7, No. 4, pp. 93-97.

WILliAMS, G. (1992), Changing Patterns of Finance in Higher Education, The Society for Research into Higher Education \& Open University Press, London.

WOLF, A. (2002), Does Education Matter? Myths about Education and Economic Growth, Penguin Books, London. 